\title{
Enzyme Activities Related to Cyanophycin Metabolism in Heterocysts and Vegetative Cells of Anabaena spp.
}

\author{
By MANJU GUPTA AND N. G. CARR* \\ Department of Biochemistry, University of Liverpool, P.O. Box 147, \\ Liverpool L69 3BX, U.K.
}

(Received 24 November 1980)

\begin{abstract}
The cyanophycin granule polypeptide (CGP) is known to serve as a nitrogen reserve protein in cyanobacteria and is mobilized during nitrogen starvation. An exopeptidase, provisionally called cyanophycinase, which degraded CGP in vitro has been studied, and its product characterized, in two $\mathrm{N}_{2}$-fixing Anabaena species. The enzyme had a $\mathrm{pH}$ optimum of $8 \cdot 5$, had no requirement for monovalent or divalent cations and was inhibited by L-arginine and $\mathrm{L}$-aspartic acid. The product of this enzyme was an aspartic acid-arginine dipeptide. A higher activity of both arg-poly(asp) synthetase and cyanophycinase was observed in extracts of heterocysts of both Anabaena species than in vegetative cells. This supports the view that CGP has a dynamic role in nitrogen metabolism of cyanobacteria as well as a storage function.
\end{abstract}

\section{INTRODUCTION}

All cyanobacteria so far examined possess electron-dense bodies, termed cyanophycin granules or structured granules (Lang, 1968; Lang et al., 1972). They consist of a polypeptide, composed only of arginine and aspartic acid, which has been shown to be multi-L-arginyl-poly(L-aspartic acid), abbreviated to arg-poly(asp) and given the trivial name cyanophycin (Simon, 1971; Simon \& Weathers, 1976; Allen \& Weathers, 1980). The unusually simple composition of this polymer, which has molecular weights between 25000 and 100000 , is reflected in its resistance to enzymic hydrolysis and to sequential breakdown by Edman degradation (Simon \& Weathers, 1976). The fluctuation in cyanophycin granule polypeptide (CGP) content of cyanobacteria reflects the relative availability of nitrogen, and the role of CGP as a nitrogen storage material has been emphasized (Simon, 1973a; Allen et al., 1980). Although reduced carbon skeletons which are central to biosynthesis can be derived from arginine and aspartic acid, Stanier \& Cohen-Bazire (1977) suggested that CGP may in addition act as an ATP supply by the breakdown of arginine. In contrast to phycocyanin, the other source of reserve nitrogen in cyanobacteria (Allen \& Smith, 1969), CGP is not synthesized on ribosomes (Simon, 1973b). Simon (1976) has purified and characterized arg-poly(asp) synthetase in extracts of vegetative cells of Anabaena cylindrica and shown it to require a 'primer' of pre-formed CGP for its activity.

Many filamentous cyanobacteria contain specialized cells - heterocysts - which are the major or sole site of $\mathrm{N}_{2}$ fixation and which exist in an interdependent relationship with their vegetative supporting cells (for reviews, see Haselkorn, 1978; Carr, 1979). Heterocysts contain amorphous polar bodies, which stain deeply with Sakaguchi reagent, indicating arginine content (Fogg, 1951). These bodies are now recognized as cyanophycin granules (Lang et al., 1972). We describe in this communication the content of CGP in cell-free extracts of heterocysts and vegetative cells of two Anabaena species and characterize its enzymic synthesis and breakdown. 


\section{METHODS}

Organisms and growth. Anabaena cylindrica (strain 1403/2a; Culture Centre of Algae and Protozoa, Cambridge) and Anabaena 7120 (PCC 7120; Institut Pasteur, Paris) were maintained and grown at $29 \pm 1{ }^{\circ} \mathrm{C}$ in the medium of Allen \& Arnon (1955) gassed with $5 \%(\mathrm{v} / \mathrm{v}) \mathrm{CO}_{2}$ in air, with a light intensity of $75 \mu \mathrm{E} \mathrm{m}^{-2} \mathrm{~s}^{-1}$. Cultures were grown in $500 \mathrm{ml}$ flasks containing $250 \mathrm{ml}$ medium supplemented with $3 \mathrm{~mm}-\mathrm{NH}_{4} \mathrm{Cl}\left(\mathrm{A}^{+}\right.$medium) when a population without heterocysts was required. To obtain a heterocyst-containing population, 101 cultures were supplied with only $0.3 \mathrm{mM}-\mathrm{NH}_{4} \mathrm{Cl}$. Nitrogen became limiting after approximately $72 \mathrm{~h}$ and heterocysts began to differentiate; after a further $24 \mathrm{~h}$, the heterocyst population was complete (approximately $10 \%$ of the cells in Anabaena 7120 and $8 \%$ in A. cylindrica). An intermediate stage of heterocyst differentiation, occurring 14 to $16 \mathrm{~h}$ after the limitation of nitrogen, consisted of 6 to $8 \%$ proheterocysts and their associated, nitrogen-limited, vegetative cells. Such a culture was termed 'differentiating filaments'.

Isolation of heterocysts. Exponentially growing heterocyst-containing filaments from 201 of culture were harvested in a continuous-flow centrifuge at room temperature; subsequent steps were carried out at $4{ }^{\circ} \mathrm{C}$. For the assay of cyanophycinase activity, organisms were washed three times in $500 \mathrm{ml} \mathrm{NP}$ buffer ( 20 mM-sodium phosphate, $\mathrm{pH} 8.5)$ and resuspended $(201$ culture in $200 \mathrm{ml})$ in TEM buffer ( $50 \mathrm{~mm}$-Tris, 25 mM-EDTA, $25 \mathrm{mM}$-mannitol, $\mathrm{pH} 8.5)$. Lysozyme $\left(1 \mathrm{mg} \mathrm{ml}^{-1}\right)$ was added and the mixture was incubated for $45 \mathrm{~min}$ at $30^{\circ} \mathrm{C}$ on a rotary shaker. Vegetative cells were then ultrasonically disrupted (for about $4 \mathrm{~s} \mathrm{ml}^{-1}$ ) in an MSE $150 \mathrm{~W}$ instrument, by a series of $15 \mathrm{~s}$ bursts. The intact heterocysts were isolated by centrifugation at $1000 \mathrm{~g}$ for $10 \mathrm{~min}$, washed twice with $200 \mathrm{ml}$ TEM buffer, and suspended in 1 to $2 \mathrm{ml} \mathrm{NP}$ buffer. Heterocyst preparations contained less than $0.5 \%$ vegetative cells.

For the assay of arg-poly(asp) synthetase, the cells were harvested and washed with TM buffer (50 mM-Tris, 5 mM- $\beta$-mercaptoethanol, 5 mM-EDTA, $\mathrm{pH} \mathrm{8.2).} \mathrm{Heterocysts} \mathrm{were} \mathrm{then} \mathrm{isolated} \mathrm{(as} \mathrm{above)} \mathrm{in} \mathrm{TEMM} \mathrm{buffer}$ (TEM buffer containing $5 \mathrm{mM}-\beta$-mercaptoethanol, $\mathrm{pH} 8 \cdot 2$ ) and finally suspended in $2 \mathrm{ml}$ TM buffer.

Harvesting of vegetative cells. Vegetative cells from an exponential phase culture grown in $\mathrm{A}^{+}$medium were harvested at $4{ }^{\circ} \mathrm{C}$, washed and suspended in $2 \mathrm{ml} \mathrm{NP}$ or TM buffer for assay of cyanophycinase and arg-poly(asp) synthetase, respectively.

Preparation of cell-free extracts. Vegetative cells in the appropriate buffer were disrupted ultrasonically $\left(15 \mathrm{~s} \mathrm{ml}^{-1}\right)$ with continuous cooling. When a heterocyst-containing filament was ultrasonically disrupted, only vegetative cells were broken, and the resultant cell-free extract was separated from debris and intact heterocysts by centrifugation. Heterocysts were broken by passing four or five times through a chilled French press at $110 \mathrm{MPa}$ (which disintegrated $99 \%$ of heterocysts) and centrifuged at $124000 \mathrm{~g}$ for $1 \mathrm{~h}$; the supernatant was used for the enzyme assays.

Radioactive labelling of CGP. Radioactively labelled CGP was prepared from vegetative cells of Anabaena 7120 and used as substrate to assay the cyanophycinase activity of both heterocysts and vegetative cells of Anabaena 7120 and A. cylindrica. Anabaena 7120 was grown in $500 \mathrm{ml} \mathrm{A}^{+}$medium, harvested after 4 to $5 \mathrm{~d}$, when the culture density was approximately $0.2 \mathrm{mg}$ dry $w t \mathrm{ml}^{-1}$, and resuspended in $200 \mathrm{ml} \mathrm{A}^{+}$medium. After $4 \mathrm{~h}$ growth chloramphenicol $\left(5 \mu \mathrm{g} \mathrm{ml}^{-1}\right)$ was added, followed $2 \mathrm{~h}$ later by $20 \mu \mathrm{Ci} \mathrm{L}-\left[5(\mathrm{n}){ }^{3} \mathrm{H} \mid\right.$ arginine (specific activity $10 \mathrm{Ci} \mathrm{mmol}^{-1} ; 370 \mathrm{GBq} \mathrm{mmol}^{-1}$ ). The organism was harvested after a further $60 \mathrm{~h}$ growth. For doubly labelled $\mathrm{CGP}, 15 \mu \mathrm{Ci} \mathrm{L}-\left[\mathrm{U}-{ }^{14} \mathrm{C}\right.$ laspartic acid (specific activity $10 \mathrm{mCi} \mathrm{mmol}{ }^{-1} ; 370 \mathrm{MBq} \mathrm{mmol}^{-1}$ ) was also added.

Isolation of cyanophycin granules. Cyanophycin granules from all types of cells were isolated by a method based on that of Simon (1973a). Labelled or unlabelled cells from $200 \mathrm{ml}$ cultures were disrupted ultrasonically and granules were washed twice in $10 \mathrm{ml} 5 \mathrm{~mm}$-sodium phosphate buffer, $\mathrm{pH} 7.5$. The pellet was resuspended in $10 \mathrm{ml} \mathrm{2 \%}$ Triton X-100 and centrifuged. This step was repeated four times followed by washing four times with $10 \mathrm{ml}$ sodium phosphate buffer. Each centrifugation following washing was carried out at $27000 \mathrm{~g}$ for $15 \mathrm{~min}$ at $4{ }^{\circ} \mathrm{C}$. Isolated granules were resuspended in 1 to $2 \mathrm{ml}$ sodium phosphate buffer, transferred to $1.5 \mathrm{ml}$ Sarstedt microcentrifuge tubes and purified by centrifugation at $12000 \mathrm{~g}$ for $30 \mathrm{~s}$ in a micro-haemocrit centrifuge. The top amorphous layer of the pellet was carefully removed and the lower white compact layer was resuspended in $1 \mathrm{ml}$ buffer and centrifuged at the same speed. Remaining top layer material was again removed and the granules were resuspended in $1 \mathrm{ml}$ buffer. When radioactively labelled granules purified by this procedure were dissolved in $0.1 \mathrm{M}-\mathrm{HCl}$ (Simon, $1973 \mathrm{a}$ ), $99.9 \%$ of the isotope was solubilized, indicating a high degree of purity.

CGP to be used as a primer for arg-poly(asp) synthetase was purified as above, except that $5 \mathrm{~mm}$ unlabelled L-arginine was added to chloramphenicol-treated cells instead of radioactively labelled arginine. CGP was assayed as described by Simon $(1973 a)$.

Assay for cyanophycinase activity. The principle of the assay was the release into the soluble fraction of radioactivity from $\mid{ }^{3} \mathrm{H}$ |arginine-labelled CGP. The standard reaction mixture contained, in a total volume of $240 \mu \mathrm{l}: 50 \mathrm{~mm}$-sodium phosphate buffer, $\mathrm{pH}$ 8.5; CGP equivalent to about $70 \mu \mathrm{g}$ arginine, labelled with $\left[{ }^{3} \mathrm{H} \mid\right.$ arginine or $\left[{ }^{3} \mathrm{H}\right]$ arginine and $\left[{ }^{14} \mathrm{C}\right]$ aspartic acid; and cell-free extract containing 150 to $200 \mu \mathrm{g}$ protein. The reaction was carried out in polycarbamate centrifuge tubes, incubated with agitation at $30{ }^{\circ} \mathrm{C}$. The reaction was stopped by transferring the tubes into ice and then to $-18{ }^{\circ} \mathrm{C}$. The thawed suspension was centrifuged at $27000 \mathrm{~g}$ 
for $15 \mathrm{~min}$ at $4{ }^{\circ} \mathrm{C}$. Protein was precipitated from the supernatant (to prevent possible quenching during isotope counting) by the addition of $60 \mu \mathrm{l} 20 \%$ (w/v) trichloroacetic acid and centrifuging at $5000 \mathrm{~g}$ for 10 to $15 \mathrm{~min}$. The supernatant was mixed with Aquasol and radioactivity was counted in an Intertechnique scintillation counter, to an accuracy of at least $1 \%$.

Characterization of product of cyanophycinase. The heterocyst enzyme was employed for the characterization of the cyanophycinase product, with the cyanophycinase assay mixture scaled up threefold. After centrifugation at $27000 \mathrm{~g}$ the supernatant was loaded on to a Bio-Gel P-2 column $(1 \times 22 \mathrm{~cm}, 17 \mathrm{ml}$ vol. $)$ without prior trichloroacetic acid precipitation. The column was pre-equilibrated with $60 \mathrm{~mm}$-sodium phosphate buffer, $\mathrm{pH} 8.5$; the flow rate was $6 \mathrm{ml} \mathrm{h}^{-1}$ and the fraction volume $0.2 \mathrm{ml}$. The column was calibrated using the following standards: cyanocobalamin (mol. wt 1355); oxidized glutathione (613); reduced glutathione (307); arginine (174). The molecular weights of the enzyme reaction products in the fractions were calculated on the basis of elution volume to void volume ratio $\left(V_{\mathrm{e}} / V_{\mathbf{0}}\right)$ as compared to the standard curve. When a Sephadex G-10 column $(1 \times 22 \mathrm{~cm})$ was employed the column volume was $13 \mathrm{ml}$ and $0.5 \mathrm{ml}$ fractions were eluted with $50 \mathrm{mM}$-sodium phosphate buffer, $\mathrm{pH} 8 \cdot 5$.

Thin-layer chromatographic analysis was carried out after precipitation of protein from the reaction mixture by 8 vol. $90 \%$ ethyl alcohol. The alcohol was evaporated, under $\mathrm{N}_{2}$, at $40^{\circ} \mathrm{C}$ and the products were dissolved in $1 \mathrm{ml}$ water at $80^{\circ} \mathrm{C}$. The $5000 \mathrm{~g}$ supernatant was extracted twice with diethyl ether. The aqueous phase was lyophilized and then dissolved in $50 \mathrm{ml}$ propan-2-ol/water $(20: 80$, by vol.): $10 \mu \mathrm{l}$ portions were spotted on $\mathrm{MN}-300$ cellulose plates $(20 \times 20 \mathrm{~cm})$ which were run in butan-1-ol/acetic acid/water $(80: 20: 20$, by vol.) Areas corresponding to arginine and aspartate were removed and their radioactivity was counted in a scintillation counter in toluene plus $0.4 \%(\mathrm{w} / \mathrm{v})$ 2,5-diphenyloxazole (PPO) and 0.01\% (w/v) 1,4-di-2-(5-phenyloxazolyl)benzene (POPOP).

Assay for arg-poly(asp) synthetase activity. The principle of the assay was the incorporation of radioactively labelled arginine or aspartate into trichloroacetic acid-insoluble material, after normal protein synthesis had been inhibited by chloramphenicol. The assay mixture (Simon, 1976) contained, in a total volume of $250 \mu \mathrm{l}$ : $50 \mathrm{mM}$-Tris, pH 8.2; $10 \mathrm{mM}$ - $\beta$-mercaptoethanol; $20 \mathrm{mM}-\mathrm{KCl} ; 20 \mathrm{mM}-\mathrm{MgCl}_{2} ; 4 \mathrm{mM}$-ATP; $34 \mu \mathrm{M}$-chloramphenicol; $0.5 \mu \mathrm{Ci}\left[{ }^{14} \mathrm{C}\right]$ aspartic acid; $1 \mu \mathrm{Ci}\left[{ }^{3} \mathrm{H}\right]$ arginine; purified CGP containing $40 \mu \mathrm{g}$ arginine; and cell-free extract containing 200 to $300 \mu \mathrm{g}$ protein. The reaction was carried out for different periods and then stopped by adding $2 \mathrm{ml}$ cold $\left(4^{\circ} \mathrm{C}\right)$ distilled water to the mixture, which was then immediately frozen at $-18{ }^{\circ} \mathrm{C}$. After thawing, the reaction mixture was centrifuged at $27000 \mathrm{~g}$ for $15 \mathrm{~min}$. The pellet was washed twice with $5 \mathrm{ml} 50 \mathrm{mM}$-Tris buffer, $\mathrm{pH} 8.0$, and then with $5 \mathrm{ml} 10 \%$ trichloroacetic acid, and recentrifuged. The pellet was dissolved in $0.5 \mathrm{ml}$ $0.1 \mathrm{M}-\mathrm{HCl}$ for $30 \mathrm{~min}$ at $30^{\circ} \mathrm{C}$ and then mixed with $3.3 \mathrm{ml}$ Aquasol, and radioactivity was counted.

Protein estimation. Protein was estimated by the microbiuret method of Itzhaki \& Gill (1964).

Heterocyst and vegetative cell counts. Isolated heterocysts and vegetative cells were counted in a haemocytometer. Vegetative filaments were broken into 2- to 4-celled sections with a homogenizer prior to counting.

Chemicals. L-[5(n) $\left.{ }^{3} \mathrm{H}\right]$ Arginine and $\mathrm{L}-\left[\mathrm{U}-{ }^{14} \mathrm{C}\right]$ aspartic acid were from The Radiochemical Centre, Amersham; Aquasol, PPO and POPOP were from New England Nuclear; amino acids and $p$-aminobenzamidine. $\mathrm{HCl}$, and glutathione (oxidized and reduced) were from Sigma; Bio-Gel P-2 was from Bio-Rad Laboratories. Cyanocobalamin and all other chemicals were purchased from BDH.

\section{RES ULTS.}

\section{Properties of the cyanophycinase reaction}

The $\mathrm{pH}$ optimum of the enzyme reaction was $8 \cdot 5$. Activity increased when the CGP concentration was increased over the range 0 to $80 \mu \mathrm{g}$ arginine equivalent. Activity also increased linearly with the amount of enzyme protein when up to $100 \mu \mathrm{g}$ enzyme protein per assay was used with $35 \mu \mathrm{g}$ arginine equivalent CGP. The release of $\left[{ }^{3} \mathrm{H}\right]$ arginine was linear with time for up to $40 \mathrm{~min}$ with extracts of vegetative cells and for up to $120 \mathrm{~min}$ with heterocyst extracts. Under the conditions used, not more than $5 \%$ of the labelled CGP substrate was converted into soluble product. The crude enzyme extract lost activity by $7 \%$ when frozen for $18 \mathrm{~h}$ at $-18^{\circ} \mathrm{C}$. The enzyme was inhibited by its end-products: $10 \mathrm{mM}$ arginine and $10 \mathrm{~mm}$ - $p$-aminobenzamidine. $\mathrm{HCl}$ (an analogue of arginine) inhibited the cyanophycinase activity by $62 \%$ and $73 \%$, respectively, while $10 \mathrm{~mm}$-aspartic acid caused only $37 \%$ inhibition.

When the enzyme extract was passed through a Sephadex G-10 column, the eluted enzyme did not show any drop in specific activity. Activity was not enhanced by the addition of $\mathrm{Na}^{+}$, 


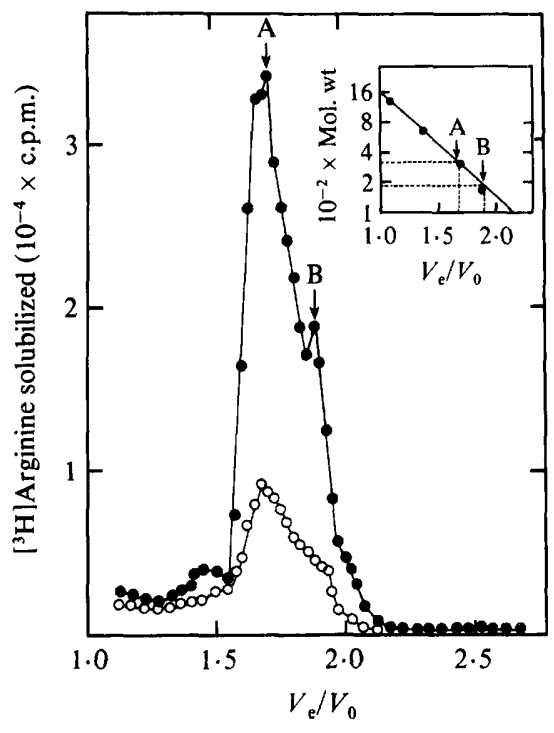

Fig. 1

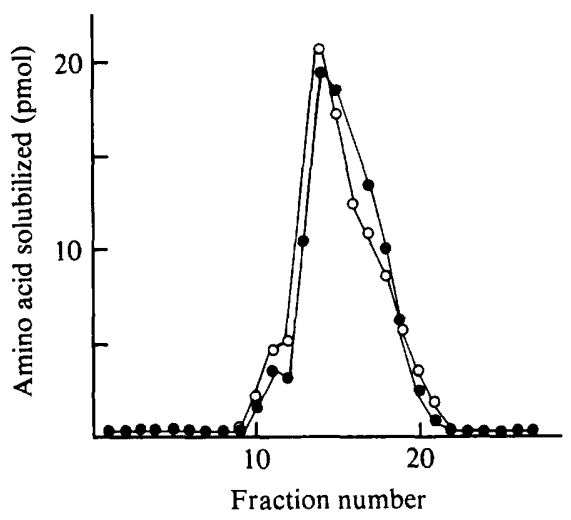

Fig. 2

Fig. 1. Distribution of $\left[{ }^{3} \mathrm{H}\right]$ arginine in fractions eluted from a Bio-Gel P-2 column after application of the products of incubating ${ }^{3} \mathrm{H}$-labelled CGP with cyanophycinase from heterocysts of Anabaena 7120 for $30 \mathrm{~min}(\mathrm{O})$ and for $2 \mathrm{~h}(\mathrm{O})$. The column was calibrated (inset) with cyanocobalamin (mol. wt 1355), oxidized glutathione (613), reduced glutathione (307) and arginine (174).

Fig. 2. Distribution of $\left[{ }^{3} \mathrm{H}\right]$ arginine $(\mathrm{O})$ and $\left[{ }^{14} \mathrm{C}\right]$ aspartic acid $(O)$ in fractions eluted from a Sephadex G-10 column after application of the products of a $2 \mathrm{~h}$ incubation of doubly labelled CGP with cyanophycinase from heterocysts of Anabaena 7120.

$\mathrm{K}^{+}, \mathrm{Ca}^{2+}, \mathrm{Mn}^{2+}$ or $\mathrm{Mg}^{2+}$ (each at 5 to $20 \mathrm{mM}$ ) to the eluted enzyme; the divalent cations in fact slightly inhibited activity. $\mathrm{NH}_{4} \mathrm{Cl}(10 \mathrm{mM})$ had no effect on cyanophycinase activity.

\section{Characterization of the product of cyanophycinase}

When the product of a $2 \mathrm{~h}$ incubation with enzyme was passed through a Bio-Gel P-2 column, the distribution of labelled arginine in the eluted fractions showed two distinct peaks (Fig. 1), corresponding to molecular weights of about 320 (A) and 180 (B). Since the molecular weight of arginine is 174 , peak B was assumed to comprise free arginine, while peak A was taken to be a dimer consisting of a peptide of aspartic acid and arginine.

When doubly labelled CGP was employed in order to examine the degree of release of each amino acid by cyanophycinase, there was an exact equivalence of the two amino acids in the peptide eluted from a Sephadex G-10 column, showing that an arg-asp fraction (rather than an asp-asp fraction) is the product of CGP breakdown (Fig. 2).

Thin-layer chromatography confirmed that only a small proportion of the soluble products of cyanophycinase were free amino acids. The major part of the released material remained at the origin, indicating its peptide nature.

\section{Arg-poly(asp) synthetase}

The cell-free extract of heterocysts of Anabaena 7120 incorporated both $\left[{ }^{3} \mathrm{H}\right.$ ]arginine and $\left[{ }^{14} \mathrm{C}\right]$ aspartic acid into CGP. Primer CGP was necessary for the synthetase activity, as reported by Simon (1976). The product of the enzyme reaction was insoluble in $10 \%$ trichloroacetic acid and soluble in $0.1 \mathrm{M}-\mathrm{HCl}$, consistent with it being CGP. The specific activity of the heterocyst enzyme from Anabaena 7120 increased linearly with the increase in 


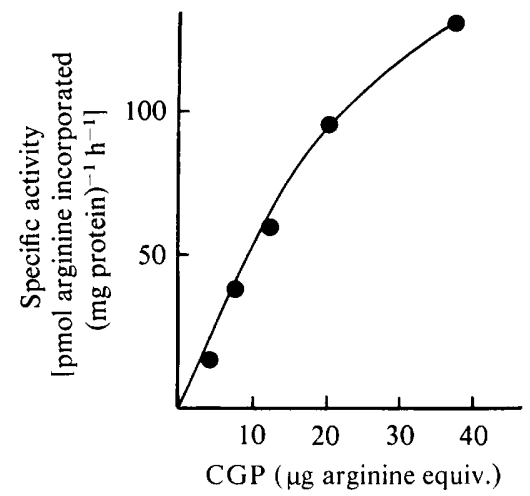

Fig. 3. Specific activity of arg-poly(asp) synthetase as a function of supplied primer concentration, in an extract of heterocysts from Anabaena 7120 . The reaction was performed with $200 \mu \mathrm{g}$ protein per assay for $40 \mathrm{~min}$.

Table 1. Activity of arg-poly(asp) synthetase in cell-free extracts of heterocysts and vegetative cells of Anabaena 7120 incubated with radioactively labelled arginine and aspartic acid

$\begin{array}{lccc}\text { Substrate } & \text { Heterocysts } & \begin{array}{c}\text { Vegetative } \\ \text { cells }\end{array} & \begin{array}{c}\text { Specific activity } \\ \text { [pmol amino acid incorporated } \\ \left.(\mathrm{mg} \text { protein })^{-1} \mathrm{~h}^{-1}\right]\end{array} \\ \begin{array}{c}\text { Activity in } \\ \text { vegetative cells } \\ \text { relative to } \\ \text { activity in } \\ \text { heterocysts }(\%)\end{array} \\ {\left[{ }^{3} \mathrm{H}\right] \text { Arginine }} & 146 & 5 & 3.4 \\ {\left[{ }^{14} \mathrm{C}\right] \text { Aspartic acid }} & 11070 & 1090 & 9.8\end{array}$

CGP primer concentration, up to $20 \mu \mathrm{g}$ arginine equivalent CGP (Fig. 3). Thereafter increase in activity became less pronounced. A CGP concentration equivalent to $40 \mu \mathrm{g}$ arginine was subsequently used for comparative experiments.

\section{Specific activities of cyanophycinase and arg-poly(asp) synthetase in vegetative cells and} heterocysts

The activity of the arg-poly(asp) synthetase was measured in Anabaena 7120 by following the incorporation of both $\left[{ }^{3} \mathrm{H}\right]$ arginine and $\left[{ }^{14} \mathrm{C}\right]$ aspartic acid into trichloroacetic acidinsoluble material. Direct comparison of the specific activities obtained with the two amino acids is not possible because each would be diluted to a different degree by the endogenous pools. Furthermore, incorporation of arginine was dependent on the pre-formation of the poly(asp) backbone of CGP (Simon, 1976). The only comparison that can be made is between the activity in vegetative cells and in heterocysts: the latter showed considerably more synthetase activity (Table 1).

Heterocysts of both Anabaena species also showed considerably greater cyanophycinase activity than vegetative cells (about 90-fold greater in Anabaena 7120 and 20 -fold in $A$. cylindrica: Table 2). Differentiating filaments, containing only proheterocysts and vegetative cells, showed much less activity than mature heterocysts. Vegetative cell extracts from $\mathrm{N}_{2}$-fixing cultures, prepared by ultrasonic treatment that did not disrupt heterocysts, contained cyanophycinase with a specific activity of $0.50 \mathrm{pmol}$ arginine solubilized (mg protein $)^{-1} \mathrm{~h}^{-1}$ in A. cylindrica and 0.57 pmol (mg protein) ${ }^{-1} \mathrm{~h}^{-1}$ in Anabaena 7120 . These activities were close to those found in extracts of cultures grown in the presence of $\mathrm{NH}_{4} \mathrm{Cl}$ (Table 2). 
Table 2. Cyanophycinase activity in heterocysts, differentiating filaments and vegetative cells of two Anabaena species

Results show the mean specific activities, with the range of values and number of determinations in parentheses.

\begin{tabular}{lccc} 
& \multicolumn{3}{c}{ Specific activity $\left[\mathrm{pmol}\right.$ arginine solubilized $\left.(\mathrm{mg} \text { protein })^{-1} \mathrm{~h}^{-1}\right]$} \\
\cline { 2 - 4 } \multicolumn{1}{c}{ Species } & Heterocysts & $\begin{array}{c}\text { Differentiating } \\
\text { filaments }\end{array}$ & $\begin{array}{c}\text { Vegetative } \\
\text { cells }\end{array}$ \\
$\begin{array}{l}\text { Anabaena } 7120 \\
\text { A. cylindrica }\end{array}$ & $35 \cdot 1(34.9-36.8)(4)$ & $1.2(1.1-1.5)(3)$ & $0.38(0.22-0.54)(3)$ \\
$17.0(15.0-20.0)(3)$ & $4.0(3.8-4.5)(3)$ & $0.77(0.51-0.99)(3)$
\end{tabular}

\section{Content of CGP in heterocysts and vegetative cells}

Simon $(1973 a)$ has shown that the actual amount of CGP is fivefold greater than the arginine measured; presumably only a proportion of arginine in CGP is available for the colorimetric estimation. The arginine content as a measure of CGP was higher in vegetative cells than in heterocysts of both Anabaena species by about $50 \%$, with significant variation between replicate experiments. Anabaena 7120 had average values of $3.9 \mu \mathrm{g}$ arginine equivalent CGP in $10^{6}$ heterocysts and $5.6 \mu \mathrm{g}$ in $10^{6}$ vegetative cells.

\section{DISCUSSION}

The presence of CGP in heterocysts was confirmed by isolation of the polymer from heterocysts that had been freed from vegetative cells; it was presumed that this was the material which stained with the Sakaguchi reaction (Fogg, 1951) and was located in the heterocyst poles. The identification of a CGP-degrading enzyme, apparently an exopeptidase, to which we give the trivial name cyanophycinase, is of interest in view of the resistance of the polymer to other proteases (Simon \& Weathers, 1976). The reaction catalysed by cyanophycinase may be written as:

$$
[\arg -\text { poly (asp) }]_{n} \rightarrow[\arg -\text { poly(asp) }]_{n-1}+\arg \text {-asp }
$$

The small amount of free arginine produced is probably the result of cleavage of the arg-asp dipeptide, and experiments to identify an enzyme causing this cleavage are now under way. The synthesis of CGP involves the establishment of a poly(asp) backbone of undetermined length, then the addition of the arginine residue to each aspartic acid (Simon, 1976). The difference between the routes of synthesis and breakdown of CGP is consistent with our knowledge of many other biopolymers.

The considerable difference between the specific activity of arg-poly(asp) synthetase obtained with the two substrates $\left[{ }^{3} \mathrm{H}\right]$ arginine and $\left[{ }^{14} \mathrm{C}\right]$ aspartic acid can be accounted for in two ways. Firstly, there may be a difference in the degree of dilution of radioactive isotope by endogenous pools of arginine and aspartic acid, which may differ. More importantly, the presence of a poly(asp) backbone of CGP is necessary for any arginine incorporation (Simon, 1976). Thus any measure of arg-poly(asp) synthetase that is based on arginine incorporation must assume the prior incorporation of aspartic acid. The point that emerges unequivocally is that arg-poly(asp) synthetase activity is considerably greater in heterocysts than in vegetative cells of Anabaena 7120.

Cyanophycinase is 20 -fold more active in heterocysts than vegetative cells in $A$. cylindrica and 90 -fold greater in the case of Anabaena 7120 . Other than nitrogenase activity this is probably the greatest enzyme difference yet observed between heterocysts and vegetative cells. Cyanophycinase activity in differentiating filaments was only slightly greater than in 
vegetative cells, which had similar activities after growth in the presence or absence of $\mathrm{NH}_{4} \mathrm{Cl}$. We conclude that nitrogen limitation as such does not induce the marked increase in cyanophycinase activity, and that the higher activity is associated only with the functioning of mature heterocysts. The role of CGP as a reserve material (Simon, 1973 a; Allen et al., 1980) is entirely consistent with its accumulation under varied environmental conditions. However, the relatively similar amounts of the polymer in heterocysts and vegetative cells, and the high activity of CGP-metabolizing enzymes in heterocysts, indicate a greater degree of turnover of CGP in heterocysts and suggest a more direct role in nitrogen assimilation. We suggest that CGP may act as a reservoir between nitrogen fixation and the export of glutamine (Thomas et al., 1977) from heterocysts into vegetative cells, thus separating the constant requirement for fixed nitrogen for biosynthesis from the possibly non-constant rates of nitrogen fixation in the heterocysts.

M.G. is a Commonwealth Fellow and the work was supported by the Science Research Council. We thank Dr R. J. Beynon for advice and discussion.

\section{REFERENCES}

Allen, M. B. \& ARnon, D. I. (1955). Studies on nitrogen-fixing blue-green algae. I. Growth and nitrogen fixation by Anabaena cylindrica Lemm. Plant Physiology 30, 366-372.

Allen, M. M., Hutchinson, F. \& Weathers, P. J. (1980). Cyanophycin granule polypeptide formation and degradation in the cyanobacterium Aphanocapsa 6308. Journal of Bacteriology 141, 687-693.

Allen, M. M. \& SMIth, A. J. (1969). Nitrogen chlorosis in blue-green algae. Archiv für Mikrobiologie 69, 114-120.

Allen, M. M. \& Weathers, P. J. (1980). Structure and composition of cyanophycin granules in a cyanobacterium Aphanocapsa 6308. Journal of Bacteriology 141, 959-962.

CARR, N. G. (1979). Differentiation in filamentous cyanobacteria. In Developmental Biology of Prokaryotes, pp. 167-201. Edited by J. H. Parish. Oxford: Blackwell Scientific Publications.

FoGG, G. E. (1951). Growth and heterocyst production in Anabaena cylindrica Lemm. III. The cytology of heterocysts. Annals of Botany 15, 23-35.

Haselkorn, R. (1978). Heterocysts. Annual Review of Plant Physiology 29, 319-344.

ITZHAKI, R. F. \& GILL, D. M. (1964). A micro-biuret method for estimating proteins. Analytical Chemistry 2, 401-410.

LANG, N. J. (1968). The fine structure of blue-green algae. Annual Review of Microbiology 22, 15-46.

LANG, N. J., Simon, R. D. \& Wolk, C. P. (1972). Correspondence of cyanophycin granules with structured granules in Anabaena cylindrica. Archiv für Mikrobiologie 83, 313-320.
Simon, R. D. (1971). Cyanophycin granules from the blue-green alga Anabaena cylindrica: a reserve material consisting of copolymers of aspartic acid and arginine. Proceedings of the National Academy of Sciences of the United States of America $\mathbf{6 8}$, 265-267.

Simon, R. D. $(1973 a)$. Measurement of the cyanophycin granule polypeptide contained in the blue-green alga Anabaena cylindrica. Journal of Bacteriology 114, 1213-1216.

Simon, R. D. $(1973 b)$. The effect of chloramphenicol on the production of cyanophycin granule polypeptide in the blue-green alga Anabaena cylindrica. Archiv für Mikrobiologie 92, 115-122.

Simon, R. D. (1976). The biosynthesis of multiL-arginyl poly(L-aspartic acid) in the filamentous cyanobacterium Anabaena cylindrica. Biochimica et biophysica acta 422, 407-418.

Simon, R. D. \& Weathers, P. J. (1976). Determination of the structure of the novel polypeptide containing aspartic acid and arginine which is found in cyanobacteria. Biochimica et biophysica acta $\mathbf{4 2 0}$, 165-176.

Stanier, R. Y. \& Cohen-Bazire, G. (1977). Phototrophic prokaryotes: the cyanobacteria. Annual Review of Microbiology 31, 225-274.

Thomas, J., Meeks, J. C., Wolk, C. P., Shaffer, P. W., Austin, S. M. \& Chien, W. S. (1977). Formation of glutamine from $\left[{ }^{13} \mathrm{~N}\right.$ lammonia, $\left[{ }^{13} \mathrm{~N}\right]$ dinitrogen and $\left[{ }^{14} \mathrm{C}\right]$ glutamate by heterocysts isolated from Anabaena cylindrica. Journal of Bacteriology 129, 1545-1555. 